OPEN ACCESS

Edited by:

Marie-Agnes Dragon-Durey,

Université Paris Descartes, France

Reviewed by:

Sophie Chauvet,

INSERM U1138 Centre de Recherche des Cordeliers, France

Betty P. Tsao,

Medical University of South Carolina,

United States

*Correspondence: Margarita López-Trascasa margarita.lopez@uam.es

Specialty section:

This article was submitted to Autoimmune and Autoinflammatory

Disorders,

a section of the journal

Frontiers in Immunology

Received: 30 November 2018 Accepted: 05 April 2019 Published: 24 April 2019

Citation:

Corvillo F, Okrój M, Nozal P. Melgosa M, Sánchez-Corral P and López-Trascasa M (2019) Nephritic Factors: An Overview of Classification,

Diagnostic Tools and Clinical Associations. Front. Immunol. 10:886.

doi: 10.3389/fimmu.2019.00886

\section{Nephritic Factors: An Overview of Classification, Diagnostic Tools and Clinical Associations}

\author{
Fernando Corvillo ${ }^{1,2}$, Marcin Okrój ${ }^{3}$, Pilar Nozal ${ }^{1,2,4}$, Marta Melgosa ${ }^{1,5}$, \\ Pilar Sánchez-Corral ${ }^{1,2}$ and Margarita López-Trascasa ${ }^{1,6 *}$
}

${ }^{1}$ Complement Research Group, Hospital La Paz Institute for Health Research (IdiPAZ), La Paz University Hospital, Madrid, Spain, ${ }^{2}$ Center for Biomedical Network Research on Rare Diseases (CIBERER U754), Madrid, Spain, ${ }^{3}$ Department of Medical Biotechnology, Intercollegiate Faculty of Biotechnology, University of Gdansk and Medical University of Gdansk, Gdansk, Poland, ${ }^{4}$ Immunology Unit, La Paz University Hospital, Madrid, Spain, ${ }^{5}$ Pediatric Nephrology Unit, La Paz University Hospital, Madrid, Spain, ${ }^{6}$ Departamento de Medicina, Universidad Autónoma de Madrid, Madrid, Spain

Nephritic factors comprise a heterogeneous group of autoantibodies against neoepitopes generated in the C3 and C5 convertases of the complement system, causing its dysregulation. Classification of these autoantibodies can be clustered according to their stabilization of different convertases either from the classical or alternative pathway. The first nephritic factor described with the capacity to stabilize C3 convertase of the alternative pathway was C3 nephritic factor (C3NeF). Another nephritic factor has been characterized by the ability to stabilize C5 convertase of the alternative pathway (C5NeF). In addition, there are autoantibodies against assembled C3/C5 convertase of the classical and lectin pathways (C4NeF). These autoantibodies have been mainly associated with kidney diseases, like C3 glomerulopathy and immune complex-associated-membranoproliferative glomerulonephritis. Other clinical situations where these autoantibodies have been observed include infections and autoimmune disorders such as systemic lupus erythematosus and acquired partial lipodystrophy. C3 hypocomplementemia is a common finding in all patients with nephritic factors. The methods to measure nephritic factors are not standardized, technically complex, and lack of an appropriate quality control. This review will be focused in the description of the mechanism of action of the three known nephritic factors (C3NeF, C4NeF, and C5NeF), and their association with human diseases. Moreover, we present an overview regarding the diagnostic tools for its detection, and the main therapeutic approach for the patients with nephritic factors.

Keywords: complement system, nephritic factor, C3 glomerulopathy, lipodystrophy, eculizumab

\section{INTRODUCTION}

The complement system is a complex molecular system with fundamental roles in apoptotic cell clearance, immune complex elimination, defense against infections, and modulation of adaptive immunity (1). Moreover, complement is capable of distinguishing between self-components and foreign agents. Through a molecular tagging system, complement labels these foreign agents to 
be eliminated by opsonophagocytosis or by direct cell lysis $(2,3)$. The complement cascade is activated by three distinct mechanisms: the classical pathway $(\mathrm{CP})$, the lectin pathway (LP) and the alternative pathway (AP) (Figure 1). These three pathways differ mainly in the initial activation steps, but all of them converge in the activation of the C3 molecule through the generation of unstable protease complex, called C3 convertases (1-4).

The activation of CP and LP pathways is triggered by the binding of antigen-antibody complexes, and through the recognition of mannose groups on bacterial surfaces, respectively. After its activation, the resulting multi-molecular complex C3 convertase (C4b2a), is responsible for cleaved C3 molecule into $\mathrm{C} 3 \mathrm{a}$ and $\mathrm{C} 3 \mathrm{~b}$ (Figure 1) (1). The next step concludes with the incorporation of $\mathrm{C} 3 \mathrm{~b}$ molecules to the C4b2a complex, and the generation of the CP/LP C5 convertase (C4b2aC3b). Finally, C5 convertase splits C5 into C5a, a proinflammatory anaphylatoxin, and $\mathrm{C} 5 \mathrm{~b}$, which incorporates to the formation of the of the membrane attack complex (MAC or C5b9), along with $\mathrm{C} 6, \mathrm{C} 7, \mathrm{C} 8$, and $\mathrm{C} 9$, on the cell surface. Two soluble proteins, called vitronectin and clusterin, regulate this process, preventing its incorporation into cell membranes (1-4) (Figure 1).

In contrast to the $\mathrm{CP}$ and $\mathrm{LP}$, the $\mathrm{AP}$ is initiated by spontaneous activation of $\mathrm{C} 3$ in plasma, which occurs through the "tick-over" $(1,2)$. This spontaneous activation results in the production of a few $\mathrm{C} 3 \mathrm{a}$ and $\mathrm{C} 3 \mathrm{~b}$ molecules. The resulting $\mathrm{C} 3 \mathrm{~b}$ molecules can then combine with factor $\mathrm{B}(\mathrm{FB})$ to form the inactive AP pro- $\mathrm{C} 3$ convertase $(\mathrm{C} 3 \mathrm{bB})$. Then $\mathrm{FB}$ is cleavage by factor $\mathrm{D}(\mathrm{FD})$, generating $\mathrm{Ba}$, which is released from the complex, and $\mathrm{Bb}$, which remains bound. The assembled $\mathrm{C} 3 \mathrm{bBb}$ complex is considered the functional C3 convertase of the AP, and is capable of amplifying complement activation by a feedback mechanisms that generates a large number of $\mathrm{C} 3 \mathrm{~b}$ molecules within a short time span (1-4) (Figure 1). There is a complement positive regulator, called properdin $(\mathrm{P})$, which can bind to the $\mathrm{C} 3 \mathrm{bBb}$ complex inducing an increase of his half-life $(1,2)$. Such as happened in CP and LP, generation of the AP C5 convertase (C3bBbC3b) cleaves $\mathrm{C} 5$ and ends in MAC formation $(1,2)$.

The convertase complexes dissociate spontaneously in a few minutes, a process that is critical to prevent autologous tissue injury. To prevent this damage, there is a group of soluble complement regulatory proteins (Factor $\mathrm{H}(\mathrm{FH})$, Factor I (FI) and $\mathrm{C} 4 \mathrm{BP}$ ) and membrane proteins (MCP/CD46, DAF/CD55, CR1/CD35, and CD59) with crucial roles in accelerate C3/C5 convertase dissociation, and/or inactivate $\mathrm{C} 3 \mathrm{~b}$ by proteolytic cleavage $(4,5)$ (Figure 1). A strict control between activation and regulation is necessary; as otherwise, the situation can result in the appearance of several diseases. Protein deficiencies or protein abnormal function due to genetic variations, or the presence

Abbreviations: AP, alternative pathway; $\mathrm{CP}$, classical pathway; LP, lectin pathway; FB, Factor B; P, Properdin; FH, factor H; FI, Factor I; NF, nephritic factor; C3NeF, C3 nephritic factor; $\mathrm{C} 4 \mathrm{NeF}, \mathrm{C} 4$ nephritic factor; $\mathrm{C} 5 \mathrm{NeF}$, C5 nephritic factor; C3G, C3 glomerulopathy; DDD, dense deposit disease; IC-MPGN, immune complexassociated membranoproliferative glomerulonephritis; APL, acquired partial lipodystrophy; SLE, systemic lupus erythematosus; C3GN, C3 glomerulonephritis. of autoantibodies against complement components, such as nephritic factors (NFs), are associated with several diseases, including C3 glomerulopathy (C3G), membranoproliferative glomerulonephritis (MPGN), acquired partial lipodystrophy (APL) or Systemic Lupus Erythematosus (SLE) (6-8).

\section{NEPHRITIC FACTORS}

\section{C3 and C5 Nephritic Factors}

NFs were first described in 1969, based on the observation that the serum from a patient with MPGN and hypocomplementemia broke down $\mathrm{C} 3$ when it was mixed with normal human serum $(9,10)$. The activity of NFs was later attributed to the stabilization of either cell-bound or fluid phase AP complement convertase by its incorporation into $\mathrm{C} 3$ convertase $(\mathrm{C} 3 \mathrm{bBb})$; therefore, it was called $\mathrm{C} 3$ nephritic factor $(\mathrm{C} 3 \mathrm{NeF})(11,12)$. After that, $\mathrm{C} 3 \mathrm{NeF}$ was characterized as IgG and IgM autoantibodies with the capacity to recognize neoepitopes of the assembled AP C3 convertase (13-18) (Figure 2A). Studies focused to characterize $\mathrm{C} 3 \mathrm{NeF}$ showed that IgG with stabilizing capacity mostly belonged to IgG1 and IgG3 subclasses $(14,15)$. Moreover, the Fab portion of the immunoglobulin retained the majority of the stabilizing function, although other studies show that the Fc portion also contributes to its functional activity $(18,19)$.

Several studies have reported that function of $\mathrm{C} 3 \mathrm{NeF}$ is dependent on the presence of $\mathrm{P}$. These P-dependent C3NeFs are responsible for activation of the $\mathrm{C} 5$ convertase, as reflected by the reduced levels of terminal complement components, and higher sC5b-9 complexes (20-23). In contrast, patients with P-independent $\mathrm{C} 3 \mathrm{NeF}$ are characterized by low C3 levels and normal levels of component of the terminal pathway $(22,23)$. In a recent study, Marinozzi et al. have designed a novel functional assay that allows the identification of patients with autoantibodies with the ability to stabilize the $\mathrm{C} 5$ convertase of the AP, which are called C5 nephritic factors (C5NeF) (Figure 2B) (24). A review of previous reports establishes that this autoantibody could be identical to the P-dependent $\mathrm{C} 3 \mathrm{NeF}$ described by Tanuma et al. (22), Paixão-Cavalcante et al. (25) and in several previous papers $(20,21)$. C5NeF has been detected as a unique nephritic factor ( $10 \%$ of cases) or as coexisting with $\mathrm{C} 3 \mathrm{NeF}$ (39\% of cases) (24). This new terminology is useful for distinguishing NFs in relation to their ability to stabilize $\mathrm{C} 3$ or $\mathrm{C} 5$ convertases.

All $\mathrm{C} 3 \mathrm{NeF}$ s increase the half-life of $\mathrm{C} 3$ convertase, because they interfere with the accelerated decay by FH, DAF, and CR1 (25-28). An interesting study used a combination of ELISA and western blot assays to show the heterogeneous control of $\mathrm{C} 3 \mathrm{NeF}$ on $\mathrm{C} 3$ convertase stabilization against spontaneous and accelerated decay (29). The authors demonstrated that some $\mathrm{C} 3 \mathrm{NeFs}$ strongly stabilized the $\mathrm{C} 3$ convertase by preventing both spontaneous and FH-mediated decay in the absence of P. Other C3NeFs, however, need $\mathrm{P}$ to prevent C3 convertase dissociation (29). Regarding their epitope specificity, most $\mathrm{C} 3 \mathrm{NeF}$ recognize a neoepitope on the assembled $\mathrm{C} 3 \mathrm{bBb}$ complex. However, autoantibodies against $\mathrm{C} 3 \mathrm{~b}$ and $\mathrm{FB}$ have recently been reported in patients with $\mathrm{C} 3 \mathrm{G}$, and these have the same capacity to increase the $\mathrm{C} 3$ convertase half-life as $\mathrm{C} 3 \mathrm{NeF}(30-32)$. The main features for $\mathrm{C} 3 \mathrm{NeF}$ and $\mathrm{C} 5 \mathrm{NeF}$ are summarized in Table $\mathbf{1}$. 


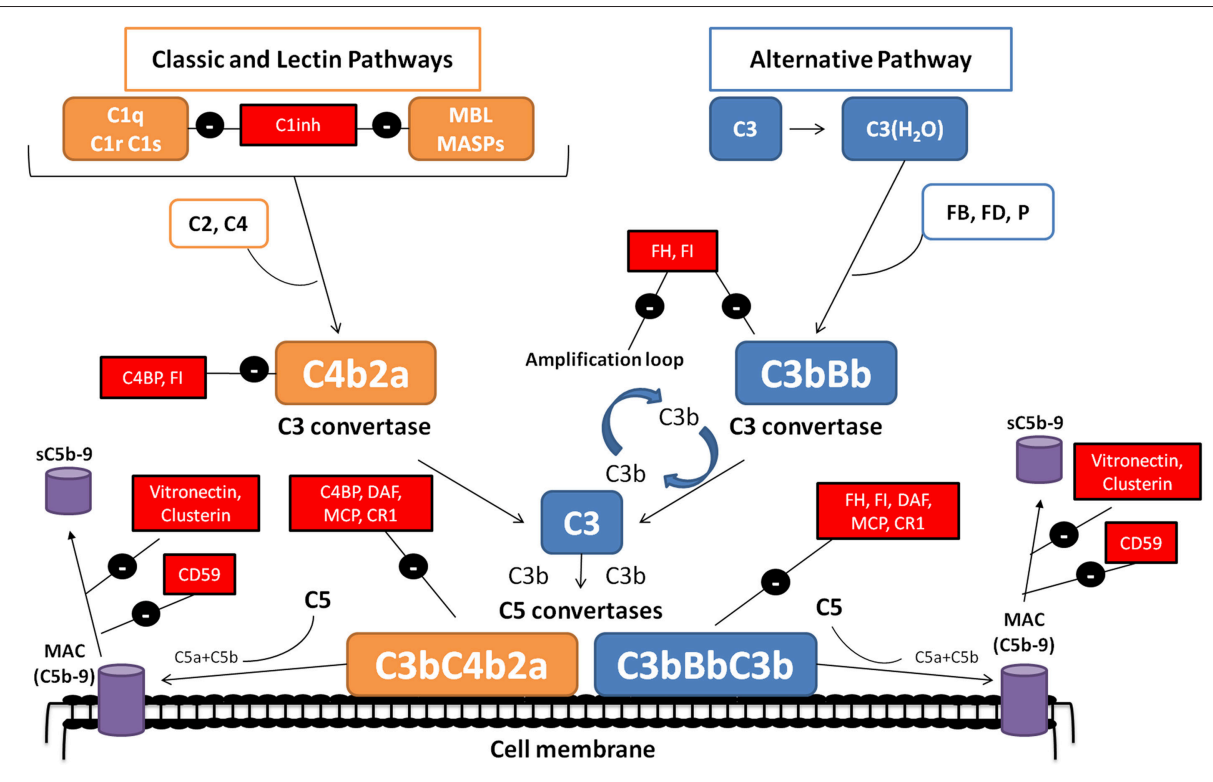

FIGURE 1 | The complement system. The complement system can be activated by three pathways. The classical (CP) and lectin (LP) pathways involve recognition of target-bound antibody or pathogen-specific carbohydrates by C1q or MBL, respectively. In the alternative pathway (AP), continuous, low-level activation of C3 by spontaneous hydrolysis of the internal $\mathrm{C} 3$ thioester, or $\mathrm{C} 3$ cleavage by plasma proteases, generates $\mathrm{C} 3\left(\mathrm{H}_{2} \mathrm{O}\right)$ or $\mathrm{C} 3 \mathrm{~b}$. Activation by any of the three pathways leads to the generation of C3 convertase complexes (C4b2a in the CP/LP and C3bBb in the AP) that cleave C3 into C3a and C3b. Additionally, the AP C3 convertase can bind properdin $(\mathrm{P})$, a positive regulator that stabilizes the enzyme, extending its half-life more than 10-fold. The C3b generated can, in turn, forms more AP C3 convertase, allowing amplification of complement activation. The binding of a new C3b molecule to the C3 convertases creates the C5 convertases (C4b2aC3b or C3bBbC3b), which cleave C5 into C5a and C5b. C5b then initiates the terminal complement pathway, which eventually leads to the formation of the membrane attack complex (C5b-9) and lysis of the target cells. Complement activation is controlled at various levels by different soluble and membrane regulatory proteins (indicated within boxes).
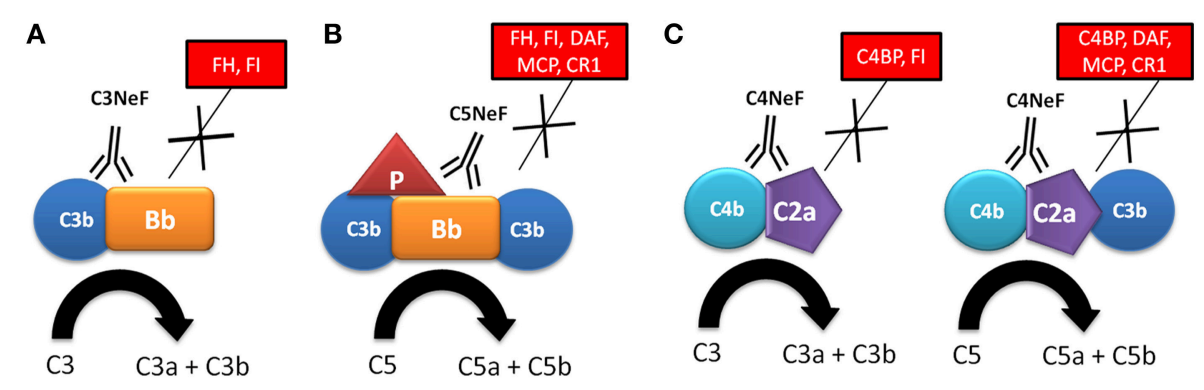

FIGURE 2 | Mechanism of action of nephritic factors. (A) C3NeF binds to a neoepitope on the C3 convertase of the alternative pathway (C3bBb), preventing its spontaneous and $\mathrm{FH}$-mediated decay, and increasing its half-life and $\mathrm{C} 3$ consumption. (B) C5NeF binds to a neoepitope on the C5 convertase of the alternative pathway in the presence of properdin $(\mathrm{P})(\mathrm{C} 3 \mathrm{bBbC} 3 \mathrm{bP})$, preventing its spontaneous and regulator-mediated decay, and increasing its half-life and $\mathrm{C} 5$ consumption. (C) $\mathrm{C} 4 \mathrm{NeF}$ binds to a neoepitope on the $\mathrm{C} 3 / \mathrm{C} 5$ convertases of the classical/lectin pathway (C4b2a/C4b2aC3b), preventing its spontaneous and regulator-mediated decay, and increasing its half-life and C3 consumption. Soluble and membrane complement regulators are indicated within boxes.

\section{C4 Nephritic Factor (C4NeF)}

$\mathrm{C} 4 \mathrm{NeFs}$ are autoantibodies that recognize and stabilize the $\mathrm{CP} / \mathrm{LP}$ C3 convertase (C4b2a) (Figure 2C), increasing its half-life in the fluid and solid phase from a few minutes to several hours (4144). They were first described in 1980 in one patient with postinfectious glomerulonephritis who had low C3 and C5 levels (41), and in 2 lupus nephritis patients (42). C4NeFs were detected in a patient with chronic glomerulonephritis (44), and in two MPGN patients with very low C3 and C5 levels who also presented $\mathrm{C} 3 \mathrm{NeF}$ autoantibodies (45). Coexistence of both $\mathrm{C} 3 \mathrm{NeF}$ and
$\mathrm{C} 4 \mathrm{NeF}$ in the same patient was corroborated upon screening of 100 MPGN patients, 10 of whom presented $\mathrm{C} 3 \mathrm{NeF}$ and $\mathrm{C} 4 \mathrm{NeF}$, and reduced C3 and C5 levels (38). The reduced C5 levels observed in these patients is explained by the additional capacity of some $\mathrm{C} 4 \mathrm{NeFs}$ to stabilize the $\mathrm{C} 5$ convertase and prevent its decay (46).

C4NeFs frequency could be underestimated. As assays for detecting $\mathrm{C} 4 \mathrm{NeFs}$ are similar to the assays for detecting $\mathrm{C} 3 \mathrm{NeFs}$ (see section Clinical Associations), the generation of C3 activation fragments could be erroneously attributed to the 
TABLE 1 | Specificity and clinical associations of nephritic factors.

\begin{tabular}{|c|c|c|}
\hline & Epitope & Clinical association (frequency) \\
\hline $\mathrm{C} 3 \mathrm{NeF}$ & $\begin{array}{l}\text { Neoepitope on } \\
\text { assembled C3 } \\
\text { convertase of the AP } \\
\text { (C3bBb) }\end{array}$ & $\begin{array}{l}\text { C3GN }(40-50 \%) \text { and DDD }(70-80 \%) \\
(7,24,25,33,34) \\
\text { IC-MPGN }(40-50 \%)(34,35) \\
\text { APL }(70-80 \%)(36,37) \\
\text { SLE }^{*}\end{array}$ \\
\hline $\mathrm{C} 4 \mathrm{NeF}$ & $\begin{array}{l}\text { Neoepitope on } \\
\text { assembled C3/C5 } \\
\text { convertase of the } \\
\text { CP/LP (C4b2a or } \\
\text { C4b2aC3b) }\end{array}$ & $\begin{array}{l}\text { C3G and IC-MPGN (3-9\%) (38-40) } \\
\text { SLE }^{\star}\end{array}$ \\
\hline $\mathrm{C} 5 \mathrm{NeF}$ & $\begin{array}{l}\text { Neoepitope on } \\
\text { assembled } \mathrm{C5} \\
\text { convertase of the AP } \\
(\mathrm{C} 3 \mathrm{bBbC} 3 \mathrm{bP})\end{array}$ & C3GN (67\%) and DDD (33\%) (24) \\
\hline
\end{tabular}

$A P$, alternative pathway; $C P$, classical pathway; $L P$, lectin pathway; C3G, C3 glomerulopathy; DDD, dense deposit disease; IC-MPGN, immune complex-associated membranoproliferative glomerulonephritis; APL, acquired partial lipodystrophy; SLE, systemic lupus erythematosus; C3GN, C3 glomerulonephritis

"The frequency of C3NeF and/or C4NeF in SLE has not been thoroughly investigated.

presence of $\mathrm{C} 3 \mathrm{NeF}$ instead of $\mathrm{C} 4 \mathrm{NeF}$; to avoid this, data on the levels of C3, C5 and terminal components in the patient's plasma should be known. Thus, $\mathrm{C} 3$ levels are lower in $\mathrm{C} 3 \mathrm{NeF}$ positive patients than in $\mathrm{C} 4 \mathrm{NeF}$ positive patients, while in $\mathrm{C} 4 \mathrm{NeF}$ positive patients reduced levels of $\mathrm{C} 5$ and most terminal complement components are observed (38).

$\mathrm{C} 4 \mathrm{NeF}$ are most likely of the IgG3 subclass (41). In vitro studies with patients' purified IgG have been used to determine the molecular mechanisms of convertase stabilization by $\mathrm{C} 4 \mathrm{NeFs}$. Protection against C4BP-mediated decay was observed (47), and later on confirmed in another study that also showed increased resistance to spontaneous decay and to the proteolytic inactivation of $\mathrm{C} 4 \mathrm{~b}$ within the C4b2a complex (43). Resistance of $\mathrm{C} 4 \mathrm{NeF}-\mathrm{C} 3$ convertase to the dissociation induced by CR1 has also been shown (48). C3 and C5 convertases stabilized by $\mathrm{C} 4 \mathrm{NeF}$ are strongly resistant to DAF-mediated decay; however, neither $\mathrm{C} 3 \mathrm{NeF}$ nor $\mathrm{C} 4 \mathrm{NeF}$ allow assembly of the $\mathrm{C} 3$ convertase in the presence of DAF (27). A recent study with $\mathrm{C} 4 \mathrm{NeF}$ s purified from C3G patients (39) confirms the increased protection against C4BP- and CR1-mediated decay, as well as stabilization of the C5 convertase. Therefore, $\mathrm{C} 4 \mathrm{NeF}$ seems to be a highly effective shield against the spontaneous and regulator-induced dissociation of the $\mathrm{CP} \mathrm{C} 3 / \mathrm{C} 5$ convertases (Figure 2C). The main features for $\mathrm{C} 4 \mathrm{NeF}$ are summarized in Table $\mathbf{1}$.

\section{DIAGNOSTIC TOOLS TO DETECT NEPHRITIC FACTORS}

Several methods for the evaluation of NFs have been reported in the literature. Although the old and very simple methods based on mixing normal and hypocomplementemic serum from suspected individuals and the subsequent identification of complement activation markers are still in use, they appear to be of low sensitivity; therefore, a number of more sophisticated protocols have been developed (25). Modern methods are based on measuring the binding of NFs to the pre-formed C3 convertase (see section Binding Assays), or measuring $\mathrm{C} 3 / \mathrm{C} 5$ convertase activity in the presence of an NF-suspected sample (see section Functional Assays) (Figure 3). However, such methods represent a substantial challenge due to the labile nature of the $\mathrm{C} 3 / \mathrm{C} 5$ convertases, and to a number of situations that mimic NF activity; like as presence of gain-of-function mutations in C3 and FB $(49,50)$. Apparently, detection of NFs remains problematic, because the 2015 European quality assessment revealed that only half of the participating laboratories properly identified C3NeF reference samples (51). Of note, there is no ideal test capable of covering all difficulties, and both binding assays and functional assays have advantages and drawbacks. Therefore, the combination of convertase assays helps not only improving the specificity of detection but also shedding light on the nature of NFs.

\section{Binding Assays}

Binding assays use convertases reconstituted from purified components on artificial surfaces such as microplates or biosensor chips. Identification of the ligand bound to the convertase complex can give rise to a diagnosis of NF. However, ligand binding may not have any influence on enzyme function, and therefore the positive results of binding assays might not be physiologically relevant. This possibility is reflected by the fact that a certain portion of $\mathrm{C} 3 \mathrm{NeF}$-positive samples detected by binding assays were negative in other functional assays, possibly representing false-positive results (25). However, binding assays performed on purified convertase components allow study the kinetics of convertase dissociation, especially when performed with surface plasmon resonance techniques (52). There are several procedures described for the detection of $\mathrm{C} 3 \mathrm{NeF}$ (53). Typically, C3b is immobilized on the microplate surface and then reacted with $\mathrm{FB}$ and FD. High yields of microplateattached alternative convertase complexes are achieved by the addition of $\mathrm{NiCl}_{2}$ (53) or $\mathrm{NiSO}_{4}$ (25), which outperforms magnesium ions normally supporting convertase formation. The most popular binding assays are enzyme-linked immunosorbent assays (ELISAs) to detect immunoglobulins bound to preformed convertase complex (CO-Ig) (Figure 3). However, such assays might not identify the non-Ig C3 activating factors (54). Another version of the ELISA-based binding assay, the so-called C3NeF stabilization (COS) assay, detects plate-bound $\mathrm{Bb}$ fragments with a polyclonal antibody (Figure 3) (25). The COS assay, like assays detecting convertase-bound Igs, begins with $\mathrm{C} 3 \mathrm{~b}$ deposition followed by the addition of test serum or purified Ig fraction together with FB, FD and optionally, P (COS-P assay) (Figure 3). Detection of $\mathrm{Bb}$ fragments on the plate surface coated with $\mathrm{C} 3 \mathrm{~b}$ indicates the presence of complete AP convertase, which normally decays within minutes when no stabilizing agent is present. Importantly, experimental data by Paixão-Cavalcante et al. showed that 36 out of 101 samples collected from patients with complement-related renal diseases were found to be positive for $\mathrm{C} 3 \mathrm{NeF}$ in a COS-P assay but only 16 out of these 36 were positive in a COS assay (25). This difference indicates that $\mathrm{C} 3 \mathrm{NeF}$ 


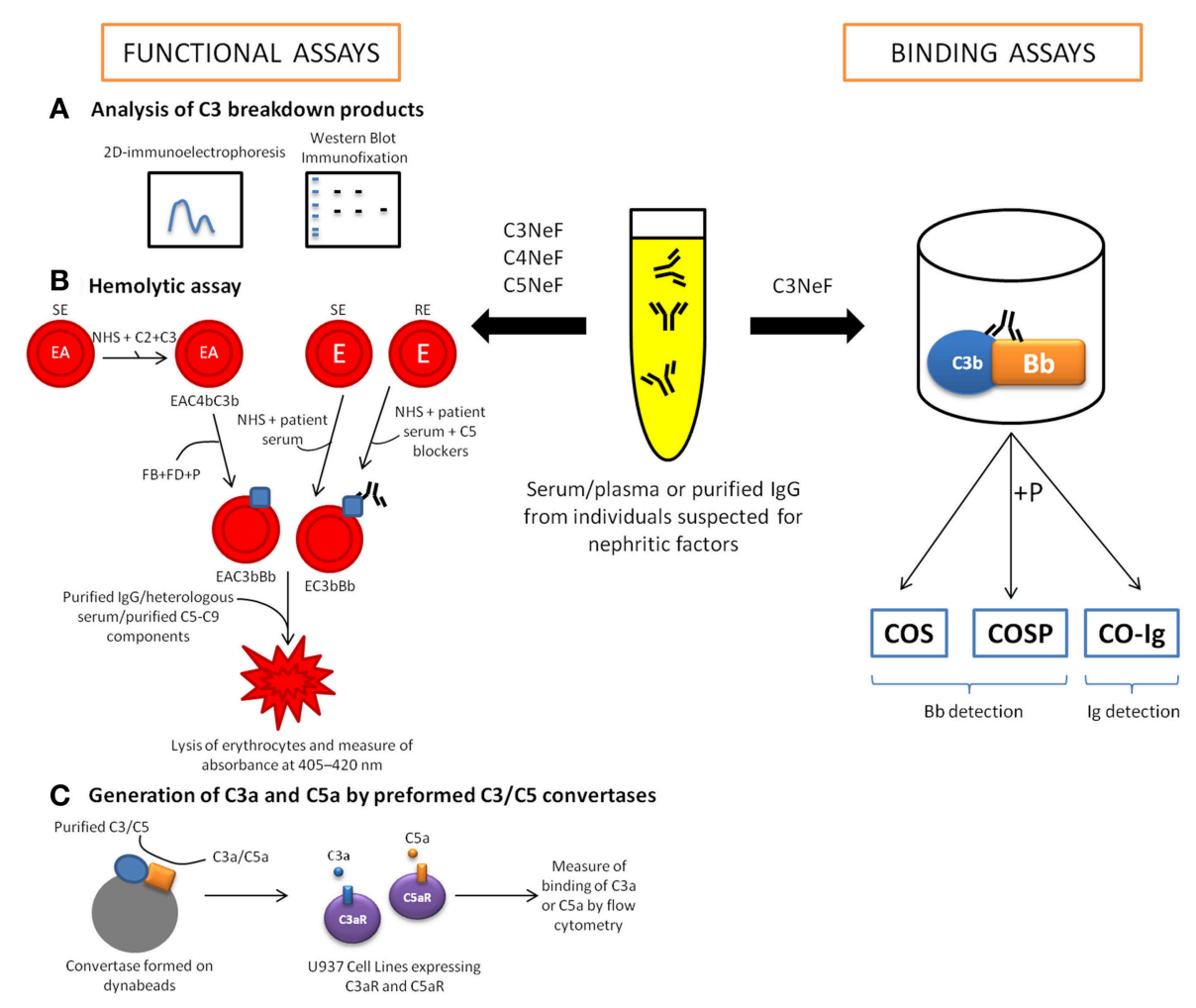

FIGURE 3 | Diagnostic tools for the detection of nephritic factors (NFs). The functional activity of C3NeF can be determined through quantifying complement activation products (mostly C3 fragments) by two-dimensional immunoelectrophoresis, immunofixation electrophoresis or western blotting (A). However, the main tools for the detection of NFs activity are the hemolytic assays, which measure the lysis of sheep (SE)/rabbit erythrocytes (RE) (B). In these assays, purified complement components are added to perform convertases on the surface SE sensitized with anti-sheep antibodies (EA). Later, purified FB, FD and P are added to form specifically alternative pathway convertase. Other assays are developed using whole serum (patient's serum and normal human serum (NHS), in ratio 1: 1) to generate convertases on the SE or RE surface. Considering that RE could be lysed by human serum, terminal pathway needs to be blocked using C5 blockers (OmCl or eculizumab). Another option to measure NF activity is through the quantification of anaphylatoxins, C3a and C5a (C). There are binding assays to detect C3NeF based on enzyme-linked immunosorbent assays (ELISA) that detect immunoglobulins bound to the preformed convertase complex (CO-lg). Other versions of the ELISA-based binding assay are the so-called C3NeF stabilization assays, which use a polyclonal antibody to detect plate-bound Bb fragment generated either in the absence (COS assay) or in the presence (COS-P assay) of P.

are very heterogeneous with regard to binding sites and that $\mathrm{P}$ might play a role in AP convertase stabilization by $\mathrm{C} 3 \mathrm{NeF}$.

\section{Functional Assays}

\section{Analysis of C3 Breakdown Products}

As mentioned earlier, the first functional assays relied on mixing control and NF-suspected sera, and further analysis of complement activation products (mostly C3 fragments) by two-dimensional immunoelectrophoresis (55), immunofixation electrophoresis (56) or western blotting (25) (Figure 3). The idea behind these assays is that the spontaneous breakdown of C3 that normally initiates the AP is augmented by convertase stabilization by NFs. Therefore, $3 \mathrm{~h}$ of incubation at $37^{\circ} \mathrm{C}$ is enough time to observe substantial $\mathrm{C} 3$ cleavage in samples containing $\mathrm{C} 3 \mathrm{NeF}$ in contrast to samples containing normal serum only. Of note, all samples found positive in assays measuring C3 breakdown products were also positive in COS$\mathrm{P}$ binding assays (however, COS-P assays detected more positive samples) but some of them were negative in CO-Ig binding assays (25). A possible explanation is that COS and COS-P assays can be considered quasi-functional assays that detect protein fragments resulting from convertase activity. The same applies to assays performed with surface plasmon resonance techniques, which monitor the association and dissociation of convertase complexes.

\section{Hemolytic Assays}

Many functional convertase assays measuring the effect of enzymatic activity use red blood cells because they provide an easy readout: the release of hemoglobin, which can be easily quantified by measuring absorbance at 405-420 nm (Figure 3). The general rule is that after deposition of active convertases, the addition of a heterologous serum (e.g., guinea pig serum, which is capable of MAC formation on human convertases but offers limited activity of regulatory proteins) or purified terminal pathway components diluted in ethylene-diamine-tetraacetic acid (EDTA)-gelatin veronal buffer will generate lytic sites. Chelating of magnesium and calcium by EDTA avoids assembly 
of new convertases but does not influence MAC formation on a platform of already assembled convertases. Depending on the version, these functional assays can analyze purified components (e.g., protein A/protein G-purified Ig fraction from individuals suspected for NFs, which is added during or just after the convertase formation step) or whole serum. The use of whole serum may introduce confounding factors like soluble convertase inhibitors, which can be present at different concentration in particular individuals. Nonetheless, the presence of NF usually prevents activity of such inhibitors and should be manifested in prolonged convertase half-life. Therefore, the assay performed with whole serum as an analyte is a rather quick screening method only showing probability of NF presence, which should be further confirmed by testing of purified Ig fraction.

\section{Assays using C3/C5 convertases assembled from purified components}

The stepwise building of convertase complex on the surface of sheep erythrocytes enables the analysis of $\mathrm{CP} / \mathrm{LP}$ and AP enzymes. In the first step, $\mathrm{C} 1$ complex is deposited followed by $\mathrm{C} 4$, which binds covalently to the membrane. Then, $\mathrm{C} 2$ together with the test sample is added, and after incubation the mixture is washed and replaced by guinea pig or rat serum (fully compatible with human serum but of higher terminal pathway efficacy) in EDTA-buffer $(39,46,57,58)$. This experimental design enables the measurement of CP/LP C3 convertase activity, whereas the addition of $\mathrm{C} 3$ molecules together with $\mathrm{C} 2$ enables the formation of C5 convertase. CP/LP C5 convertase is also formed to deposit AP convertases. Covalent binding of $\mathrm{C} 3 \mathrm{~b}$ is followed by the removal of noncovalently bound $\mathrm{C} 1$ and $\mathrm{C} 2$ by prolonged incubation in $10 \mathrm{mM}$ EDTA-buffer. Later, FB, FD, and $\mathrm{P}$ are added, thus forming AP convertases $(57,58)$. After this step, purified Igs purified from patients are used to evaluate NF capacity. This method cannot ensure a clear distinction between C3 and C5 AP convertase activity, but such attempts can be performed either by titrating $\mathrm{C} 3$ and thus manipulating $\mathrm{C} 3 \mathrm{~b}$ density (59) or by developing lytic sites by mixing purified C5-C9 components $\pm \mathrm{C} 3$ (57). An alternative method of $\mathrm{C} 3 \mathrm{~b}$ deposition is incubation of erythrocytes with $\mathrm{C} 3$ and trypsin at $22^{\circ} \mathrm{C}(59,60)$.

\section{Functional assays with whole serum}

The stepwise formation of convertases from isolated complement components allows the analysis of the purified Ig fraction from an NF-suspected individual, but it also presents certain limitations. A major drawback is the inability to reproduce the physiological serum context, where many proteins are potentially capable of influencing convertases' activity. Therefore, convertase-interacting components identified in assays based on purified complement proteins might not accurately reflect physiological interactions. Convertase assays performed with whole serum are based on a similar design, i.e., convertase formation on erythrocytes as the first step, and generation of lytic sites by addition of EDTA-serum in the second step. Sheep erythrocytes sensitized with antisheep antibodies (e.g., amboceptor) offer the possibility of forming CP/LP C3 convertase (C4b2a) when erythrocytes are incubated in $\mathrm{C} 3$-depleted serum (61). The complement cascade proceeds up to the step of $\mathrm{C} 3$ convertase but no further. Similarly, incubation in C5-depleted serum results in the formation of C5 CP/LP convertase C4b2aC3b (61). The high efficacy of $\mathrm{CP} / \mathrm{LP}$ convertase formation on sensitized sheep erythrocytes enables the application of low serum concentrations $(<1 \%)$, excluding the possibility of AP convertase formation, which demands a higher (2\%) serum content. Rabbit erythrocytes, which spontaneously activate AP when incubated with human serum, are used for assays of AP convertase. However, this method is unable to distinguish between $\mathrm{C} 3$ and $\mathrm{C} 5$ convertases, given that both of them contain C3b. Carrying out the reaction in ethylene glycol-bis $(\beta-$ aminoethyl ether)- $N, N, N^{\prime}, N^{\prime}$-tetraacetic acid (EGTA)-buffer excludes the activation of CP/LP, which demands calcium and magnesium, whereas AP only requires magnesium (not affected by EGTA).

The idea of blocking the complement cascade at the level of C5 gives rise to another version of functional convertase assays that can be performed in whole serum, e.g., collected directly from the patient. To this end, $\mathrm{C} 5$ inhibitors such as eculizumab or Ornithodoros moubata complement inhibitor (OmCI) have been successfully applied (49). Testing whole serum excludes a precise diagnosis of NFs, but it is a useful screening test for searching any components that interfere with convertase activity and/or stability. Recently, this assay was successfully validated in a cohort of C3G patients. The results revealed that the combined analysis of patient's serum and purified Ig fraction properly distinguished patients with convertasestabilizing activity localized in the Ig fraction (with positive readouts in serum and Ig fraction) from those with familial aHUS caused by gain-of-function mutations in complement components (positive readout only in serum) (62). This method was also successfully applied to diagnose $\mathrm{C} 4 \mathrm{NeF}$ in a C3G patient who did not present any other abnormalities in complement proteins and was negative for $\mathrm{C} 3 \mathrm{NeF}$ and other autoantibodies against AP components (40). Technically, convertase assays with whole patient's serum demand mixing of patient's sample with normal human serum, usually in 1:1 ratio. Since NF presence is often associated with hypocomplementemia, low content of complement components in unmixed patient's serum results in low amplitude and delayed peak of convertase activity, which may mask convertase-stabilizing effect. However, addition of normal human serum as a source of complement components to NF-containing, hypocomplementemic serum, allows readouts for convertases of prolonged / enhanced activity (49). It is worth mentioning that the first hemolysis-based, two-step assay intended to diagnose $\mathrm{C} 3 \mathrm{NeF}$ in patient serum was described more than 30 years ago (63) and was later modified $(64,65)$. The so-called Rother assay is still in use in some diagnostic laboratories but it often gives inconclusive results. This test uses sheep erythrocytes, which are not an optimal target for AP activation. The kinetics of this process are slower than for analogous AP activation on rabbit erythrocytes, and therefore it is theoretically possible to extract a time point when convertases are already formed but MAC is not yet assembled. In practice, choosing such a time point is arbitrary and will not necessarily work for every individual serum tested. Indeed, many samples 
cause hemolysis in the first step of this assay, and thus preclude a reliable diagnosis.

An emerging problem for functional convertase assays in detecting NFs is the lack of widely available standards. The most commonly used strategy is to compare results obtained with the results of a reference serum (a highly-positive sample), which has limited availability. This problem is combined with the batchto-batch differences in erythrocytes, giving rise to high interassay variability, and the inability to strictly compare the values obtained in two different laboratories. A possible solution is to use gain-of-function mutants of convertase-forming proteins, which mimic the effect of NFs. For example, a recombinant FB K323E mutant has been proposed as a reference for $\mathrm{C} 3 \mathrm{NeF}$ detection (50).

\section{Generation of $\mathrm{C} 3 \mathrm{a}$ and $\mathrm{C} 5 \mathrm{a}$ by Preformed C3/C5 Convertases}

Another option for measuring convertase activity is to quantify the anaphylatoxins $\mathrm{C} 3 \mathrm{a}$ and $\mathrm{C} 5 \mathrm{a}$, which are products of $\mathrm{C} 3$ and C5 cleavage by the C3 and C5 convertases, respectively. In this assays, the formation of convertases from purified complement components takes place on the surface of beads. Thereafter, the substrates (C3 or C5) are added together with the tested sample, and the supernatant containing anaphylatoxins is transferred to a culture of reporter cells, previously transfected with $\mathrm{C} 3 \mathrm{aR}$ or $\mathrm{C} 5 \mathrm{aR}$. The intensity of the readout in calcium mobilization assays is proportional to the amount of $\mathrm{C} 3 \mathrm{a}$ and $\mathrm{C} 5 \mathrm{a}$ generated; therefore, this assay enables to distinguish between C3 and C5 convertase activities (66). Such method, not yet demonstrated usefulness for NF detection would be compatible with purified Ig fraction as an analyte.

\section{CLINICAL ASSOCIATIONS}

\section{C3 Glomerulopathy/Membranoproliferative Glomerulonephritis}

C3G is a recently adopted term to refer to a few rare kidney diseases caused by dysregulation of the AP, and characterized by significant C3 deposition in the glomeruli with minimal or no presence of immunoglobulins (67-69). Although there is no a specific histological pattern, most of the $\mathrm{C} 3 \mathrm{G}$ cases correspond to some types of the previously denominated MPGN. C3G is classified into Dense Deposit Disease (DDD) and C3 glomerulonephritis (C3GN) on the basis of the electron microscopy findings. Dense Deposit Disease is characterized by distinctive highly electron-dense intermembranous deposits whereas C3GN is characterized by mesangial, intramembranous, subendotelial and sometimes subepithelial deposits (67-72).

$\mathrm{C} 3 \mathrm{NeF}$ has been detected mainly in patients with immune complex-associated-MPGN (IC-MPGN) (40-50\%) and in patients with C3G (40-80\%) (7). Approximately $80 \%$ of patients with DDD and in $40 \%-50 \%$ of patients with C3GN $(51,72)$ are positive for $\mathrm{C} 3 \mathrm{NeF}$. Recently, Donadelli et al. published a study providing an interesting method to detect and characterize $\mathrm{C} 3 \mathrm{NeF}$ in patients with $\mathrm{C} 3 \mathrm{G}$ and IC-MPGN
(29). The authors reported that most of the patients with DDD had $\mathrm{C} 3 \mathrm{NeF}$ that stabilized $\mathrm{C} 3$ convertase in the absence of $\mathrm{P}$, while in the remaining patients (C3GN and IC-MPGN) $\mathrm{C} 3 \mathrm{NeF}$ was P-dependent $(\mathrm{C} 5 \mathrm{NeF})$, resulting in both $\mathrm{C} 3$ and C5 convertase dysregulation (29). These results are reliable with the previous observation that $\mathrm{C} 3 \mathrm{NeF}$ targets both $\mathrm{C} 3$ and C5 convertases in $67 \%$ of patients with C3GN (24), and that terminal pathway dysregulation is significantly higher in C3GN than in $\operatorname{DDD}(24,29)$. Moreover, our group documented that a subset of $\mathrm{C} 3 \mathrm{G}$ patients with low $\mathrm{P}$ levels (most of them C3GN) was characterized by C5 consumption and high sC5b-9 levels in plasma (33). However, although our results are consistent with the presence of $\mathrm{C} 5 \mathrm{NeF}$, we could not prove it due to the lack of a specific assay to detect this autoantibody.

The pathogenic role of $\mathrm{C} 3 \mathrm{NeF}$ in $\mathrm{C} 3 \mathrm{G}$ has been debated for a long time. Although $\mathrm{C} 3 \mathrm{NeF}$ are closely linked with $\mathrm{C} 3 \mathrm{G}$, they have been detected in healthy individuals, suggesting that this autoantibody is part of the normal immune repertoire (73, 74). Therefore, a fundamental unanswered question is whether $\mathrm{C} 3 \mathrm{NeF}$ is the cause of the disease, or whether $\mathrm{C} 3 \mathrm{NeF}$ is a consequence of the disease process that then acts exacerbating the disease pathology $(17,74,75)$. Moreover, plasma C3 consumption and disease severity do not always correlate with the presence and activity of $\mathrm{C} 3 \mathrm{NeF}$ (76-78). Autoantibodies related to complement components, such as anti-FB, anti$\mathrm{C} 3 \mathrm{~b}$, anti-FH or other autoantibodies (e.g., ANAs, ANCAs or cryoglobulins) have been detected in smaller percentages of patients (79). Overall, in the series from Mayo Clinic, 13.4\% of $\mathrm{C} 3 \mathrm{G}$ patients were positive for autoantibodies other than $\mathrm{C} 3 \mathrm{NeF}(80)$.

$\mathrm{C} 4 \mathrm{NeFs}$ autoantibodies have been mainly found in patients with MPGN (38, 44, 45, 81). A study in 100 patients with hypocomplementemic MPGN showed that as many as 19 patients had $\mathrm{C} 4 \mathrm{NeF}$ (alone or in combination with $\mathrm{C} 3 \mathrm{NeF}$ ) (38). The 10 patients having both $\mathrm{C} 3 \mathrm{NeF}$ and $\mathrm{C} 4 \mathrm{NeF}$ presented low C3, C5, and terminal complement component (C6C9) levels, as well as massive C3 deposits in the kidneys by immunofluorescence microscopy; moreover, they presented therapy-resistant hypocomplementemia, a higher incidence of nephritic syndrome and a poorer prognosis than patients positive for only $\mathrm{C} 3 \mathrm{NeF}$ or $\mathrm{C} 4 \mathrm{NeF}$. These 10 patients would have been diagnosed of $\mathrm{C} 3 \mathrm{G}$ according to current criteria (70). Another interesting observation in this study is that one patient was subsequently $\mathrm{C} 3 \mathrm{NeF}$ positive, $\mathrm{C} 3 \mathrm{NeF}$ negative, and $\mathrm{C} 4 \mathrm{NeF}$ positive, suggesting than autoantibody specificity can change along disease evolution.

More recently, a C4NeF that reduced decay of the CP C3 and C5 convertases was detected in 1 out of 13 C3G patients (40). The patient had reduced C3 levels, but C4 and FB levels were normal. C4NeFs have been also found in 4/100 C3GN patients, and in $1 / 68$ DDD patients, representing $3 \%$ of the $168 \mathrm{C} 3 \mathrm{G}$ patients included in the study (39); 1 of these patients also had anti-FH autoantibodies, and another patient had $\mathrm{C} 3 \mathrm{NeF}$. The low frequency of $\mathrm{C} 4 \mathrm{NeF}$-positive patients (3\%) in comparison with $\mathrm{C} 3 \mathrm{NeF}$-positive patients (52\%) in this large and well documented $\mathrm{C} 3 \mathrm{G}$ series suggests that the actual contribution 
of $\mathrm{C} 4 \mathrm{NeF}$ to the pathogenic mechanism is less relevant than the contribution of $\mathrm{C} 3 \mathrm{NeF}$, and it could be associated with an infectious trigger. This possibility is in line with the authors' observation that kidney biopsies from their $\mathrm{C} 4 \mathrm{NeF}$-positive patients are suggestive of post-infectious glomerulonephritis which evolved into $\mathrm{C} 3 \mathrm{G}$.

\section{Acquired Partial Lipodystrophy (APL)}

APL or Barraquer-Simons syndrome (ORPHA:79087) is an ultra-rare disease characterized by progressive loss of adipose tissue starting from the face and then extend to the neck, shoulders, upper extremities and then to the thorax. Patients may accumulate fat excess in the lower extremities after puberty, especially female patients (36). APL is more frequent in females than males (4:1) (82). Metabolic syndrome and its comorbidities are absent or infrequent in this syndrome (83). However, autoimmune diseases, particularly SLE and dermatomyositis, have been reported in patients with $\operatorname{APL}(36,84)$.

Adipsin is an adipokine produced by mature adipocytes (85). In 1992, White et al. shown that human adipsin was identical to complement FD and that it major source was located in the adipose tissue (86). Moreover, adipocytes also express $\mathrm{C} 3, \mathrm{FB}$ and complement regulators such as $\mathrm{P}$ and $\mathrm{FH}$, and consequently complement is connected to adipocyte biology (87). Indeed, complement system functions on adipose tissue, as preadipocyte differentiation and triacylglyceride synthesis, have been described (88).

C3 hypocomplementemia in relation with the presence of $\mathrm{C} 3 \mathrm{NeF}$ have been reported in almost all patients with APL (8284, 89-103). Therefore, as a consequence of the presence of C3NeF, approximately $20 \%$ of patients with APL develop C3G in a period of 8 years after the onset of lipodystrophy, and some of them evolve to end-stage renal disease requiring renal transplantation (83). Although complement dysregulation is a common mechanism in $\mathrm{C} 3 \mathrm{G}$ and APL, the exact mechanism of fat loss remains unclear (87). There is one experimental study which described complement-mediated lysis of adipocytes in vitro by $\mathrm{C} 3 \mathrm{NeF}(87,104)$. However, the proposal fails to answer the key question of not all patients with $\mathrm{C} 3 \mathrm{NeF}$ develop lipodystrophy.

\section{SLE and Infections}

C3NeF have been described in patients with SLE, associated in most cases with partial lipodystrophy and/or DDD (90, 95, 96, 105-111). However, there are several studies describing patients with lupus nephritis, complement abnormalities and the presence of autoantibodies against AP proteins in absence of C3NeF (112114). For example, our group published a case of lupus nephritis with autoantibodies against $\mathrm{C} 3, \mathrm{FB}$ and $\mathrm{P}$, which was negative for $\mathrm{C} 3 \mathrm{NeF}$ (112). Other authors reported that approximately $30 \%$ of patients with lupus nephritis were positive for anti-C3 autoantibodies (113). These autoantibodies have a similar effect as $\mathrm{C} 3 \mathrm{NeF}$, which should be taken into consideration during the diagnosis.

$\mathrm{C} 3 \mathrm{NeFs}$ have been detected in patients with meningococcal infections, without renal impairment (115-121). By contrast, there are several cases series of post-streptococcal acute glomerulonephritis associated with $\mathrm{C} 3 \mathrm{NeF}$ activity (122-125).

C4NeFs have also been found in a few SLE patients (42), and occasionally following streptococcal (41) or meningococcal (46) infections. The latter is a peculiar case of a $\mathrm{C} 4 \mathrm{NeF}$ autoantibody that did not provoke a renal phenotype, but it was found in a patient with severe meningococcal disease. This C4NeF autoantibody stabilized the C3 and C5 convertases from the $\mathrm{CP}$ and generated $\mathrm{C} 3$ deficiency by increased consumption (46).

\section{DIAGNOSTIC APPROACH TO IDENTIFY NEPHRITIC FACTORS}

Several renal diseases are caused by complement dysregulation, and while the most common causes of impaired complement regulation are pathogenic mutations or anti-FH autoantibodies in atypical hemolytic uremic syndrome (aHUS), in C3G NFs are the most frequent finding $(34,69)$. Although definitive diagnosis should be based on light and electron microscopy findings of kidney biopsy, some laboratory tests may support the diagnosis.

After suspicion or definitive diagnosis of $\mathrm{C} 3 \mathrm{G}, \mathrm{C} 3 \mathrm{NeF}$ s have to be screened in the first steps, together with serum $\mathrm{C} 3$ levels. Other parameters included in the current laboratory diagnostic protocol are commented below.

Serum C3 and C4 levels can be measured fast and easily by automated methods, as nephelometry or turbidimetry, but normal C3 levels do not exclude NF presence. Complement activation can also be assessed by measuring C3d, FB, P and sC5b9, not only to demonstrate AP dysregulation but to differentiate between $\mathrm{C} 3 / \mathrm{C} 4 \mathrm{NeF}$ and $\mathrm{C} 5 \mathrm{NeF}(33,51,126)$.

Serum from C3G patients should be screened for autoantibodies (16), including anti-FH (55, 127, 128), antiFB (31, 129), and anti-C3 (32), all of them causing alternative pathway dysregulation, but the presence of any of these autoantibodies do not exclude NF existence, as anti-FH autoantibodies are frequently associated with $\mathrm{C} 3 \mathrm{NeF}$ in pediatric C3G patients (130). FH deficiency is associated with DDD and C3GN $(131,132)$, as it leads to totally uncontrolled AP activation. Besides serum FH levels, a genetic study is necessary because single point mutations in $\mathrm{FH}$ gene causing $\mathrm{C} 3 \mathrm{GN}$ have been described $(102,133)$.

Genetic screening of AP regulators and convertase components should be undertaken in a complete complement study of $\mathrm{C} 3 \mathrm{G}$ patients. Common and pathogenic variants associated with $\mathrm{C} 3 \mathrm{G}$ have been described in FH, FI, FB, CD46, C3 and thrombomodulin genes, influencing on long-term outcome $(5,34,35)$. Again, the presence of any mutation or variant do not exclude NF existence, as it's shown in a French C3G series, where $\mathrm{C} 3 \mathrm{NeF}$ was present in $50 \%$ of patients carrying mutations in complement genes (34).

Defective complement regulation has been demonstrated in $C 3$ and $C F B$ mutations associated with $\mathrm{C} 3 \mathrm{G}$; these mutations impair C3b inactivation by FI (134) increase convertase 
resistance to dissociation by FH (135), or promote high-affinity binding of C3 to FB (136).

A genetic and protein approach to study the Factor H-Related (FHR) proteins is also recommended, as mutations and gene rearrangements causing $\mathrm{FH}$ deregulation have been reported over the last years in C3G patients (137-143).

\section{MANAGEMENT AND THERAPEUTIC PERSPECTIVES FOR PATIENTS WITH NEPHRITIC FACTORS}

In the last years, there has been an important progress in the knowledge about treatments for autoimmune diseases. The presence of NFs should be considered the main autoimmune cause of diseases as C3G and IC-MPGN. In most of consensus reports, the experts indicate that treatment is directed to improve clinical parameters. However, a specific disease-directed treatment for patients with NFs has not been established. There are no randomized trials able to generate therapeutic decisions, so all current recommendations are based on low-quality evidence since the patients' series include a heterogeneous and limited number of cases. Therapies are divided into common treatments indicated to all autoimmune diseases and specific complement blocking drugs:

- Plasma Exchange Therapy/Plasmapheresis: In order to remove NFs, plasma exchange has been used with irregular efficacy. A combined treatment based on plasma exchange and immunosuppressants has proved useful in patients with C3G positive for $\mathrm{C} 3 \mathrm{NeF}$ (144). However, with these results it was difficult to evaluate the effect of plasma exchange since the treatments were administered all together. An interesting work showed that using long-term plasmapheresis removed $\mathrm{C} 3 \mathrm{NeF}$ activity from the serum of patients with DDD (145).

- Immunosuppressive Therapy: These treatments are focused to limit and/or reduce the production of NFs, and they have mainly been proved in patients with C3G and MPGN. The benefit of long-term alternate-day steroid therapy for idiopathic MPGN has been suggested; however, these studies include a combination of patients with different types of MPGN, limiting possible conclusions $(75,146,147)$. An interesting report from the Spanish Group for Glomerular Disease Study showed the effectiveness of the combination of mycophenolate mofetil (MMF) and glucocorticoids in patients with C3GN (148). This study compared the clinical evolution of three groups of C3GN patients: one without glucocorticoids treatment, one with glucocorticoids but no MMF and another one based on MMF plus glucocorticoids. The results showed that eight out of ten patients with $\mathrm{C} 3 \mathrm{NeF}(80 \%)$ were more likely to achieve remission with this treatment. However, this clinical improvement could not be attributed to $\mathrm{C} 3 \mathrm{NeF}$ disappearance because it determination was not performed in all patients during the whole course of the treatment. A similar although less impressive response was described in a large cohort from the Mayo Clinic (80).

- Monoclonal Antibody Therapy: Antibody-producing B celltargeted therapies should be effective in patients with
C3NeF, but the data using a monoclonal anti-CD20 antibody (rituximab) have not been consistent regarding $\mathrm{C} 3 \mathrm{NeF}$ activity and clinical response (149-151). The experience on the use of rituximab in MPGN, C3GN, and DDD with or without NFs is limited to case reports and retrospective case series. Patients with IC-MPGN who were treated with rituximab showed partial and complete responses in the majorities of cases, while treatment was not effective in most C3GN and DDD cases (152).

- Complement Directed Therapies: Complement blocking agents such as eculizumab (Soliris) have been also tried in patients with NFs as the only pathogenic cause or in combination with mutations in complement components $(153,154)$. Almost all authors coincide in that eculizumab therapy should be considered after the failure of immunosuppressive and plasma exchange treatments to improve renal function. A large series using eculizumab in C3G have been published by Le Quintrec et al. from France (154). Briefly, $23 \%$ of their patients had a global clinical response, while $23 \%$ had a partial response and the remaining $54 \%$ were nonresponders. The patients with a good clinical response had lower glomerular filtration, a more rapidly progressive course and more extracapillary proliferation as determined by kidney biopsy (154). Parameters including age, extent of renal fibrosis, nephrotic syndrome, C3 levels, C3NeF activity, sC5b-9 concentration or pathogenic complement gene variants did not differ between responders and nonresponders (154). There are several reports that show that eculizumab may be a specific and useful treatment in C3NeF-related DDD $(103,151)$. A potential benefit of eculizumab treatment was suggested for the five C4NeFpositive patients described by Zhang et al. (39), who presented elevated plasma levels of sC5b-9.

New complement modulators targeting C3 convertase activity, such as soluble CR1 (sCR1), have been proved in sporadic cases of C3G (155). The in vitro activity of sCR1 prevents the hemolysis of rabbit erythrocytes caused by $\mathrm{C} 3 \mathrm{NeF}$ with greater effectiveness than FH. The administration of sCR1 to Cfh-/-/huCR1-Tg mouse resulted in markedly reduction of C3 deposits along the glomerulus. However, C3 staining not changed before and after treatment in an 8-year-old girl positive for C3NeF with biopsy-proven DDD although the authors observed a transient improvement in $\mathrm{C} 3$ serum levels and a decreased of sC5b-9.

\section{AUTHOR CONTRIBUTIONS}

All authors listed have made a substantial, direct and intellectual contribution to the work, and approved it for publication.

\section{FUNDING}

This work was supported from Instituto de Salud Carlos III (ISCIII, Ministerio de Economía y Competitividad) and Fondos FEDER (PI15-00255 to ML-T and PI16-00723 to PS-C). 
Complemento II-CM network (B2017/BMD3673 to ML-T and PS-C). FC was supported by Fundación SENEFRO (grant to
ML-T). MO was supported by National Science Centre (Poland) grant 2015/18/M/NZ6/00334.

\section{REFERENCES}

1. Merle NS, Church SE, Fremeaux-Bacchi V, Roumenina LT. Complement system part I - molecular mechanisms of activation and regulation. Front Immunol. (2015) 6:262. doi: 10.3389/fimmu.2015.00262

2. de Córdoba SR. Complement genetics and susceptibility to inflammatory disease. lessons from genotype-phenotype correlations. Immunobiology. (2016) 221:709-14. doi: 10.1016/j.imbio.2015.05.015

3. Noris M, Remuzzi G. Overview of complement activation and regulation. Semin Nephrol. (2013) 33:479-92. doi: 10.1016/j.semnephrol.2013.08.001

4. Hajishengallis G, Reis ES, Mastellos DC, Ricklin D, Lambris JD. Novel mechanisms and functions of complement. Nat Immunol. (2017) 18:128898. doi: 10.1038/ni.3858

5. Wong EKS, Kavanagh D. Diseases of complement dysregulationan overview. Semin Immunopathol. (2018) 40:49-64. doi: 10.1007/s00281-017-0663-8

6. Alexander MP, Fervenza FC, De Vriese AS, Smith RJH, Nasr SH, Cornell LD, et al. C3 glomerulonephritis and autoimmune disease: more than a fortuitous association? J Nephrol. (2016) 29:203-9. doi: 10.1007/s40620-015-0218-9

7. Noris M, Donadelli R, Remuzzi G. Autoimmune abnormalities of the alternative complement pathway in membranoproliferative glomerulonephritis and C3 glomerulopathy. Pediatric Nephrol. (2018) doi: 10.1007/s00467-018-3989-0. [Epub ahead of print].

8. Ricklin D, Reis ES, Lambris JD. Complement in disease: a defence system turning offensive. Nat Rev Nephrol. (2016) 12:383-401. doi: 10.1038/nrneph.2016.70

9. Spitzer RE, Vallota EH, Forristal J, Sudora E, Stitzel A, Davis NC, et al. Serum C'3 lytic system in patients with glomerulonephritis. Science. (1969) 164:436-7.

10. Arroyave CM, Vallota EH, Müller-Eberhard HJ. Lysis of human erythrocytes due to activation of the alternate complement pathway by nephritic factor (C3NeF). J Immunol. (1974) 113:764-8.

11. Daha MR, Fearon DT, Austen KF. C3 nephritic factor (C3NeF): stabilization of fluid phase and cell-bound alternative pathway convertase. J Immunol. (1976) 116:1-7.

12. Daha MR, Austen KF, Fearon DT. The incorporation of $\mathrm{C} 3$ nephritic factor $(\mathrm{C} 3 \mathrm{NeF})$ into a stabilized $\mathrm{C} 3$ convertase, $\mathrm{C} 3 \mathrm{bBb}(\mathrm{C} 3 \mathrm{NeF})$, and its release after decay of convertase function. J Immunol. (1977) 119:812-7.

13. Davis AE, Ziegler JB, Gelfand EW, Rosen FS, Alper CA. Heterogeneity of nephritic factor and its identification as an immunoglobulin. Proc Natl Acad Sci USA. (1977) 74:3980-3. doi: 10.1073/pnas.74.9.3980

14. Davis AE, Gelfand EW, Schur PH, Rosen FS, Alper CA. IgG subclass studies of C3 nephritic factor. Clin Immunol Immunopathol. (1978) 11:98-101. doi: 10.1016/0090-1229(78)90207-6

15. Williams DG, Bartlett A, Duffus P. Identification of nephritic factor as an immunoglobulin. Clin Exp Immunol. (1978) 33:425-9.

16. Józsi M, Reuter S, Nozal P, López-Trascasa M, Sánchez-Corral P, Prohászka Z, Uzonyi B. Autoantibodies to complement components in C3 glomerulopathy and atypical hemolytic uremic syndrome. Immunol Lett. (2014) 160:163-71. doi: 10.1016/j.imlet.2014.01.014

17. Levy Erez D, Meyers KE, Sullivan KE. C3 nephritic factors: a changing landscape. J Allergy Clin Immunol. (2017) 140:57-9. doi: 10.1016/j.jaci.2017.02.018

18. Scott DM, Amos N, Sissons JG, Lachmann PJ, Peters DK. The immunogloblin nature of nephritic factor (NeF). Clin Exp Immunol. (1978) 32:12-24.

19. Daha MR, van Es LA. Further evidence for the antibody nature of C3 nephritic factor (C3NeF). J Immunol. (1979) 123:755-8.

20. Mollnes TE, Ng YC, Peters DK, Lea T, Tschopp J, Harboe M. Effect of nephritic factor on $\mathrm{C} 3$ and on the terminal pathway of complement in vivo and in vitro. Clin Exp Immunol. (1986) 65:73-9.
21. Clardy CW, Forristal J, Strife CF, West CD. A properdin dependent nephritic factor slowly activating C3, C5, and C9 in membranoproliferative glomerulonephritis, types I and III. Clin Immunol Immunopathol. (1989) 50:333-47. doi: 10.1016/0090-1229 (89)90141-4

22. Tanuma Y, Ohi H, Hatano M. Two types of C3 nephritic factor: properdindependent $\mathrm{C} 3 \mathrm{NeF}$ and properdin-independent $\mathrm{C} 3 \mathrm{NeF}$. Clin Immunol Immunopathol. (1990) 56:226-38. doi: 10.1016/0090-1229(90)90144-F

23. Varade WS, Forristal J, West CD. Patterns of complement activation in idiopathic membranoproliferative glomerulonephritis, types I, II, and III. Am J Kidney Dis. (1990) 16:196-206. doi: 10.1016/S0272-6386 (12)81018-3

24. Marinozzi M-C, Chauvet S, Le Quintrec M, Mignotet M, Petitprez $\mathrm{F}$, Legendre $\mathrm{C}$, et al. C5 nephritic factors drive the biological phenotype of C3 glomerulopathies. Kidney Int. (2017) 92:1232-41. doi: 10.1016/j.kint.2017.04.017

25. Paixão-Cavalcante D, López-Trascasa M, Skattum L, Giclas PC, Goodship TH, de Córdoba SR, et al. Sensitive and specific assays for C3 nephritic factors clarify mechanisms underlying complement dysregulation. Kidney Int. (2012) 82:1084-92. doi: 10.1038/ki.2012.250

26. Weiler JM, Daha MR, Austen KF, Fearon DT. Control of the amplification convertase of complement by the plasma protein beta1H. Proc Natl Acad Sci USA. (1976) 73:3268-72. doi: 10.1073/pnas.73.9.3268

27. Ito S, Tamura N, Fujita T. Effect of decay-accelerating factor on the assembly of the classical and alternative pathway $\mathrm{C} 3$ convertases in the presence of $\mathrm{C} 4$ or C3 nephritic factor. Immunology. (1989) 68:449-52.

28. Daha MR, Kok DJ, Van Es LA. Regulation of the C3 nephritic factor stabilized C3/C5 convertase of complement by purified human erythrocyte C3b receptor. Clin Exp Immunol. (1982) 50:209-14.

29. Donadelli R, Pulieri P, Piras R, Iatropoulos P, Valoti E, Benigni A, et al. Unraveling the molecular mechanisms underlying complement dysregulation by nephritic factors in C3G and IC-MPGN. Front Immunol. (2018) 9:2329. doi: 10.3389/fimmu.2018.02329

30. Daha MR, Van Es LA. Stabilization of homologous and heterologous cell-bound amplification convertases, $\mathrm{C} 3 \mathrm{bBb}$, by $\mathrm{C} 3$ nephritic factor. Immunology. (1981) 43:33-8.

31. Chen Q, Müller D, Rudolph B, Hartmann A, Kuwertz-Bröking E, Wu K, et al. Combined C3b and Factor B autoantibodies and MPGN Type II. N Engl J Med. (2011) 365:2340-2. doi: 10.1056/NEJMc1107484

32. Marinozzi MC, Roumenina LT, Chauvet S, Hertig A, Bertrand D, Olagne J, et al. Anti-factor B and anti-C3b autoantibodies in C3 glomerulopathy and Ig-associated membranoproliferative GN. J Am Soc Nephrol. (2017) 28:1603-13. doi: 10.1681/ASN.2016030343

33. Corvillo F, Bravo García-Morato M, Nozal P, Garrido S, Tortajada A, Rodríguez de Córdoba $S$, et al. Serum properdin consumption as a biomarker of C5 convertase dysregulation in C3 glomerulopathy. Clin Exp Immunol. (2016) 184:118-25. doi: 10.1111/cei.12754

34. Servais A, Noël L-H, Roumenina LT, Le Quintrec M, Ngo S, Dragon-Durey $\mathrm{M}-\mathrm{A}$, et al. Acquired and genetic complement abnormalities play a critical role in dense deposit disease and other C3 glomerulopathies. Kidney Int. (2012) 82:454-64. doi: 10.1038/ki.2012.63

35. Iatropoulos P, Noris M, Mele C, Piras R, Valoti E, Bresin E, et al. Complement gene variants determine the risk of immunoglobulin-associated MPGN and C3 glomerulopathy and predict long-term renal outcome. Mol Immunol. (2016) 71:131-42. doi: 10.1016/j.molimm.2016.01.010

36. Garg A. Acquired and inherited lipodystrophies. N Engl J Med. (2004) 350:1220-34. doi: 10.1056/NEJMra025261

37. Corvillo F, López-Trascasa M. Acquired partial lipodystrophy and C3 glomerulopathy: dysregulation of the complement system as a common pathogenic mechanism. Nefrologia. (2018) 38:258-66. doi: 10.1016/j.nefro.2017.10.002 
38. Ohi H, Yasugi T. Occurrence of $\mathrm{C} 3$ nephritic factor and $\mathrm{C} 4$ nephritic factor in membranoproliferative glomerulonephritis (MPGN). Clin Exp Immunol. (1994) 95:316-21. doi: 10.1111/j.1365-2249.1994.tb06530.x

39. Zhang Y, Meyer NC, Fervenza FC, Lau W, Keenan A, Cara-Fuentes G, et al. C4 Nephritic factors in C3 glomerulopathy: a case series. Am J Kidney Dis. (2017) 70:834-43. doi: 10.1053/j.ajkd.2017.07.004

40. Blom AM, Corvillo F, Magda M, Stasiłojć G, Nozal P, Pérez-Valdivia MÁ, et al. Testing the activity of complement convertases in serum/plasma for diagnosis of C4NeF-mediated C3 glomerulonephritis. J Clin Immunol. (2016) 36:517-27. doi: 10.1007/s10875-016-0290-5

41. Halbwachs L, Leveillé M, Lesavre P, Wattel S, Leibowitch J. Nephritic factor of the classical pathway of complement: immunoglobulin $\mathrm{G}$ autoantibody directed against the classical pathway C3 convetase enzyme. J Clin Invest. (1980) 65:1249-56. doi: 10.1172/JCI109787

42. Daha MR, Hazevoet HM, Vanes LA, Cats A. Stabilization of the classical pathway C3 convertase C42, by a factor F-42, isolated from serum of patients with systemic lupus erythematosus. Immunology. (1980) 40:417-24.

43. Gigli I, Sorvillo J, Mecarelli-Halbwachs L, Leibowitch J. Mechanism of action of the C4 nephritic factor. deregulation of the classical pathway of C3 convertase. J Exp Med. (1981) 154:1-12. doi: 10.1084/jem.154.1.1

44. Fujita T, Sumita T, Yoshida S, Ito S, Tamura N. C4 nephritic factor in a patient with chronic glomerulonephritis. J Clin Lab Immunol. (1987) 22:65-70.

45. Tanuma Y, Ohi H, Watanabe S, Seki M, Hatano M. C3 nephritic factor and $\mathrm{C} 4$ nephritic factor in the serum of two patients with hypocomplementaemic membranoproliferative glomerulonephritis. Clin Exp Immunol. (1989) 76:82-5.

46. Miller EC, Chase NM, Densen P, Hintermeyer MK, Casper JT, Atkinson JP. Autoantibody stabilization of the classical pathway C3 convertase leading to C3 deficiency and Neisserial sepsis: C4 nephritic factor revisited. Clin Immunol. (2012) 145:241-50. doi: 10.1016/j.clim.2012.09.007

47. Daha MR, van Es LA. Relative resistance of the F-42-stabilized classical pathway C3 convertase to inactivation by C4-binding protein. J Immunol. (1980) 125:2051-4.

48. Fischer E, Kazatchkine MD, Mecarelli-Halbwachs L. Protection of the classical and alternative complement pathway C3 convertases, stabilized by nephritic factors, from decay by the human C3b receptor. Eur J Immunol. (1984) 14:1111-4. doi: 10.1002/eji.1830141209

49. Blom AM, Volokhina EB, Fransson V, Strömberg P, Berghard L, Viktorelius $\mathrm{M}$, et al. A novel method for direct measurement of complement convertases activity in human serum: measurement of complement convertases in serum. Clin Exp Immunol. (2014) 178:142-53. doi: 10.1111/cei.12388

50. Urban A, Borowska A, Felberg A, van den Heuvel L, Stasiłojć G, Volokhina E, et al. Gain of function mutant of complement factor B K323E mimics pathogenic $\mathrm{C} 3 \mathrm{NeF}$ autoantibodies in convertase assays. Autoimmunity. (2018) 51:18-24. doi: 10.1080/08916934.2017.1423286

51. Prohászka Z, Nilsson B, Frazer-Abel A, Kirschfink M. Complement analysis 2016: clinical indications, laboratory diagnostics and quality control. Immunobiology. (2016) 221:1247-58. doi: 10.1016/j.imbio. 2016.06.008

52. Harris CL, Abbott RJM, Smith RA, Morgan BP, Lea SM. Molecular dissection of interactions between components of the alternative pathway of complement and decay accelerating factor (CD55). J Biol Chem. (2005) 280:2569-78. doi: 10.1074/jbc.M410179200

53. Seino J, vd Wall Bake WL, van Es LA, Daha MR. A novel ELISA assay for the detection of C3 nephritic factor. J Immunol Methods. (1993) 159:221-7. doi: 10.1016/0022-1759(93)90160-9

54. Bartlow BG, Roberts JL, Lewis EJ. Nonimmunoglobulin C3 activating factor in membranoproliferative glomerulonephritis. Kidney Int. (1979) 15:294302. doi: $10.1038 /$ ki.1979.38

55. Zhang Y, Meyer NC, Wang K, Nishimura C, Frees K, Jones M, et al. Causes of alternative pathway dysregulation in dense deposit disease. Clin J Am Soc Nephrol. (2012) 7:265-74. doi: 10.2215/CJN.07900811

56. Koch FJ, Jenis EH, Valeski JE. Test for C3 nephritic factor activity by immunofixation electrophoresis. Am J Clin Pathol. (1981) 76:63-7. doi: $10.1093 /$ ajcp/76.1.63

57. Krych-Goldberg M, Hauhart RE, Subramanian VB, Yurcisin BM, Crimmins DL, Hourcade DE, et al. Decay accelerating activity of complement receptor type 1 (CD35). two active sites are required for dissociating C5 convertases. J Biol Chem. (1999) 274:31160-8. doi: 10.1074/jbc.274.44.31160

58. Okroj M, Mark L, Stokowska A, Wong SW, Rose N, Blackbourn DJ, et al. Characterization of the complement inhibitory function of rhesus rhadinovirus complement control protein (RCP). J Biol Chem. (2009) 284:505-14. doi: 10.1074/jbc.M806669200

59. Rawal N, Pangburn M. Formation of high-affinity C5 convertases of the alternative pathway of complement. J Immunol. (2001) 166:2635-42. doi: 10.4049/jimmunol.166.4.2635

60. Rawal N, Pangburn MK. C5 convertase of the alternative pathway of complement. kinetic analysis of the free and surface-bound forms of the enzyme. J Biol Chem. (1998) 273:16828-35. doi: 10.1074/jbc.273. 27.16828

61. Okroj M, Holmquist E, King BC, Blom AM. Functional analyses of complement convertases using C3 and C5-depleted sera. PLoS ONE. (2012) 7:e47245. doi: 10.1371/journal.pone.0047245

62. Michels MAHM, van de Kar NCAJ, Okrój M, Blom AM, van Kraaij SAW, Volokhina EB, et al. Overactivity of alternative pathway convertases in patients with complement-mediated renal diseases. Front Immunol. (2018) 9:612. doi: 10.3389/fimmu.2018.00612

63. Rother U. A new screening test for C3 nephritis factor based on a stable cell bound convertase on sheep erythrocytes. J Immunol Methods. (1982) 51:101-7. doi: 10.1016/0022-1759(82)90386-6

64. West CD. A hemolytic method for the measurement of nephritic factor. J Immunol Methods. (2008) 335:1-7. doi: 10.1016/j.jim. 2007.12.001

65. López-Trascasa M, Marín MA, Fontán G. C3 nephritic factor determination. a comparison between two methods. J Immunol Methods. (1987) 98:77-82. doi: 10.1016/0022-1759(87)90438-8

66. Zwarthoff SA, Berends ETM, Mol S, Ruyken M, Aerts PC, Józsi M, et al. Functional characterization of alternative and classical pathway C3/C5 convertase activity and inhibition using purified models. Front Immunol. (2018) 9:1691. doi: 10.3389/fimmu.2018.01691

67. Sethi S, Fervenza FC. Membranoproliferative glomerulonephritis: pathogenetic heterogeneity and proposal for a new classification. Semin Nephrol. (2011) 31:341-8. doi: 10.1016/j.semnephrol.2011.06.005

68. Sethi S, Fervenza FC. Membranoproliferative glomerulonephritisa new look at an old entity. $N$ Engl J Med. (2012) 366:1119-31. doi: 10.1056/NEJMra1108178

69. Riedl M, Thorner P, Licht C. C3 Glomerulopathy. Pediat Nephrol. (2017) 32:43-57. doi: 10.1007/s00467-015-3310-4

70. Fakhouri F, Frémeaux-Bacchi V, Noël L-H, Cook HT, Pickering MC. C3 glomerulopathy: a new classification. Nat Rev Nephrol. (2010) 6:494-9. doi: 10.1038/nrneph.2010.85

71. Cook HT. C3 glomerulopathy. F1000Res. (2017) 6:248. doi: 10.12688/f1000research.10364.1

72. Pickering MC, D’Agati VD, Nester CM, Smith RJ, Haas M, Appel GB, et al. C3 glomerulopathy: consensus report. Kidney Int. (2013) 84:1079-89. doi: 10.1038/ki.2013.377

73. Egan M, Sullivan K, Frazer-Abel A, Cunningham-Rundles C. A healthy female with C3 hypocomplementemia and C3 Nephritic Factor. Clin Immunol. (2016) 169:14-5. doi: 10.1016/j.clim.2016.06.001

74. Smith RJH, Harris CL, Pickering MC. Dense deposit disease. Mol Immunol. (2011) 48:1604-10. doi: 10.1016/j.molimm.2011.04.005

75. Niel O, Dallocchio A, Thouret M-C, Guigonis V, Cassuto É, Frémeaux-Bacchi V, et al. C3 nephritic factor can be associated with membranous glomerulonephritis. Pediat Nephrol. (2015) 30:353-5. doi: 10.1007/s00467-014-3004-3

76. Schwertz R, Rother U, Anders D, Gretz N, Schärer K, Kirschfink M. Complement analysis in children with idiopathic membranoproliferative glomerulonephritis: a long-term follow-up. Pediatr Allergy Immunol. (2001) 12:166-72. doi: 10.1034/j.1399-3038.2001. 012003166.x

77. Cameron JS, Turner DR, Heaton J, Williams DG, Ogg CS, Chantler C, et al. Idiopathic mesangiocapillary glomerulonephritis. comparison of types I and II in children and adults and long-term prognosis. Am J Med. (1983) 74:175-92. doi: 10.1016/0002-9343(83)90606-X 
78. Schena FP, Pertosa G, Stanziale P, Vox E, Pecoraro C, Andreucci VE. Biological significance of the $\mathrm{C} 3$ nephritic factor in membranoproliferative glomerulonephritis. Clin Nephrol. (1982) 18:240-6.

79. Nicolas C, Vuiblet V, Baudouin V, Macher M-A, Vrillon I, BiebuyckGouge $\mathrm{N}$, et al. C3 nephritic factor associated with C3 glomerulopathy in children. Pediat Nephrol. (2014) 29:85-94. doi: 10.1007/s00467013-2605-6

80. Ravindran A, Fervenza FC, Smith RJH, De Vriese AS, Sethi S. C3 glomerulopathy: ten years' experience at mayo clinic. Mayo Clin Proc. (2018) 93:991-1008. doi: 10.1016/j.mayocp.2018.05.019

81. Seino J, Kinoshita Y, Sudo K, Horigome I, Sato H, Narita M, et al. Quantitation of C4 nephritic factor by an enzyme-linked immunosorbent assay. J Immunol Methods. (1990) 128:101-8. doi: 10.1016/0022-1759(90)90468-B

82. Hussain I, Garg A. Lipodystrophy syndromes. Endocrinol Metab Clin North Am. (2016) 45:783-97. doi: 10.1016/j.ecl.2016.06.012

83. Brown RJ, Araujo-Vilar D, Cheung PT, Dunger D, Garg A, Jack M, et al. The diagnosis and management of lipodystrophy syndromes: a multisociety practice guideline. J Clin Endocrinol Metab. (2016) 101:4500-11. doi: 10.1210/jc.2016-2466

84. Misra A, Peethambaram A, Garg A. Clinical features and metabolic and autoimmune derangements in acquired partial lipodystrophy: report of 35 cases and review of the literature. Medicine (Baltimore). (2004) 83:18-34. doi: 10.1097/01.md.0000111061.69212.59

85. Rosen BS, Cook KS, Yaglom J, Groves DL, Volanakis JE, Damm $\mathrm{D}$, et al. Adipsin and complement factor D activity: an immunerelated defect in obesity. Science. (1989) 244:1483-7. doi: 10.1126/science. 2734615

86. White RT, Damm D, Hancock N, Rosen BS, Lowell BB, Usher P, et al. Human adipsin is identical to complement factor $\mathrm{D}$ and is expressed at high levels in adipose tissue. J Biol Chem. (1992) 267:9210-3.

87. López-Lera A, Corvillo F, Nozal P, Regueiro JR, Sánchez-Corral P, LópezTrascasa M. Complement as a diagnostic tool in immunopathology. Semin Cell Dev Biol. (2018) 85:86-97. doi: 10.1016/j.semcdb. 2017.12.017

88. Pattrick M, Luckett J, Yue L, Stover C. Dual role of complement in adipose tissue. Mol Immunol. (2009) 46:755-60. doi: 10.1016/j.molimm.2008.09.013

89. Sissons JG, West RJ, Fallows J, Williams DG, Boucher BJ, Amos N, et al. The complement abnormalities of lipodystrophy. N Engl J Med. (1976) 294:461-5. doi: 10.1056/NEJM197602262940902

90. Jasin HE. Systemic lupus erythematosus, partial lipodystrophy and hypocomplementemia. J Rheumatol. (1979) 6:43-50.

91. Myers B, Chambers R, Anderson A, Barry R, Wallington T, Whicher J. C3 nephritic factor in an individual with recurrent viral infection and lipodystrophy. J Clin Lab Immunol. (1986) 19:201-4.

92. Pollock J, Wood B, Kelly JP. Membranoproliferative glomerulonephritis, type II and partial lipodystrophy in an adult. Am J Kidney Dis. (1986) 8:274-6. doi: 10.1016/S0272-6386(86)80041-5

93. Perrot H, Delaup JP, Chouvet B. [Barraquer and simons lipodystrophy. complement anomalies and cutaneous leukocytoclasic vasculitis]. Ann Dermatol Venereol. (1987) 114:1083-91.

94. Power DA, Ng YC, Simpson JG. Familial incidence of C3 nephritic factor, partial lipodystrophy and membranoproliferative glomerulonephritis. Q $J$ Med. (1990) 75:387-98.

95. Font J, Herrero C, Bosch X, Cervera R, Ingelmo M, Mascaró JM. Systemic lupus erythematosus in a patient with partial lipodystrophy. $J$ Am Acad Dermatol. (1990) 22:337-40. doi: 10.1016/0190-9622 (90)70042-G

96. Cronin CC, Higgins TJ, Molloy M. Lupus, C3 nephritic factor and partial lipodystrophy. QJM. (1995) 88:298-9.

97. Wayte J, Bird G, Wilkinson JD. The clinical significance of partial lipoatrophy and C3 hypocomplementaemia: a report of two cases. Clin Exp Dermatol. (1996) 21:131-4. doi: 10.1111/j.1365-2230.1996.tb00036.x

98. Bennett WM, Bardana EJ, Wuepper K, Houghton D, Border WA, Götze O, et al. Partial lipodystrophy, C3 nephritic factor and clinically inapparent mesangiocapillary glomerulonephritis. Am J Med. (1977) 62:75760. doi: 10.1016/0002-9343(77)90879-8
99. Mathieson PW, Peters DK. Lipodystrophy in MPGN type II: the clue to links between the adipocyte and the complement system. Nephrol Dial Transplant. (1997) 12:1804-6. doi: 10.1093/ndt/12.9.1804

100. Levy Y, George J, Yona E, Shoenfeld Y. Partial lipodystrophy, mesangiocapillary glomerulonephritis, and complement dysregulation. An autoimmune phenomenon. Immunol Res. (1998) 18:55-60. doi: $10.1007 / \mathrm{BF} 02786513$

101. Lenane P, Murphy G. Partial lipodystrophy and renal disease. Clin Exp Dermatol. (2000) 25:605-7. doi: 10.1046/j.1365-2230.2000.00717.x

102. Wong EKS, Anderson HE, Herbert AP, Challis RC, Brown P, Reis GS, et al. Characterization of a factor $\mathrm{H}$ mutation that perturbs the alternative pathway of complement in a family with membranoproliferative GN. J Am Soc Nephrol. (2014) 25:2425-33. doi: 10.1681/ASN. 2013070732

103. Ozkaya O, Nalcacioglu H, Tekcan D, Genc G, Meydan BC, Ozdemir $\mathrm{BH}$, et al. Eculizumab therapy in a patient with dense-deposit disease associated with partial lipodystropy. Pediat Nephrol. (2014) 29:1283-7. doi: 10.1007/s00467-013-2748-5

104. Mathieson PW, Würzner R, Oliveria DB, Lachmann PJ, Peters DK. Complement-mediated adipocyte lysis by nephritic factor sera. J Exp Med. (1993) 177:1827-31. doi: 10.1084/jem.177.6.1827

105. Walport MJ, Davies KA, Botto M, Naughton MA, Isenberg DA, Biasi D, et al. C3 nephritic factor and SLE: report of four cases and review of the literature. QJM. (1994) 87:609-15.

106. Hristova MH, Stoyanova VS. Autoantibodies against complement components in systemic lupus erythematosus - role in the pathogenesis and clinical manifestations. Lupus. (2017) 26:1550-5. doi: 10.1177/0961203317709347

107. Arroyave CM, Wilson MR, Tan EM. Serum factors activating the alternative complement pathway in autoimmune disease: description of two different factors from patients with systemic lupus erythematosus. I Immunol. (1976) 116:821-6.

108. Daha MR, Van Es LA. Modulation of complement by autoimmune antibodies isolated from sera of patients with membranoproliferative glomerulonephritis and systemic lupus erythematosus. Neth $\mathrm{J}$ Med. (1982) 25:202-7.

109. Waldo FB, Forristal J, Beischel L, West CD. A circulating inhibitor of fluid-phase amplification. C3 convertase formation in systemic lupus erythematosus. J Clin Invest. (1985) 75:1786-95. doi: 10.1172/ JCI111891

110. Hiramatsu M, Tsokos GC. A factor activating complement via the alternative pathway in the supernatants of B cell lines transformed by Epstein-Barr virus and in sera obtained from patients with systemic lupus erythematosus. Int Arch Allergy Appl Immunol. (1988) 86:209-14. doi: 10.1159/000234573

111. Sheeran TP, White RH, Raafat F, Jackson MA, Kumararatne DS, Situnayake RD. Hypocomplementaemia, C3 nephritic factor and type III mesangiocapillary glomerulonephritis progressing to systemic lupus erythematosus. Br J Rheumatol. (1995) 34:90-2. doi: 10.1093/rheumatology/34.1.90

112. Nozal P, Garrido S, Martínez-Ara J, Picazo ML, Yébenes L, Álvarez-Doforno $\mathrm{R}$, et al. Case report: lupus nephritis with autoantibodies to complement alternative pathway proteins and C3 gene mutation. BMC Nephrol. (2015) 16:40. doi: 10.1186/s12882-015-0032-6

113. Vasilev VV, Noe R, Dragon-Durey M-A, Chauvet S, Lazarov VJ, Deliyska BP, et al. Functional characterization of autoantibodies against complement component C3 in patients with lupus nephritis. J Biol Chem. (2015) 290:25343-55. doi: 10.1074/jbc.M115.647008

114. Birmingham DJ, Bitter JE, Ndukwe EG, Dials S, Gullo TR, Conroy S, et al. Relationship of circulating anti-C3b and anti-C1q IgG to lupus nephritis and its flare. Clin J Am Soc Nephrol. (2016) 11:47-53. doi: 10.2215/CJN. 03990415

115. Thompson RA, Yap PL, Brettle RB, Dunmow RE, Chapel H. Meningococcal meningitis associated with persistent hypocomplementaemia due to circulating C3 nephritic factor. Clin Exp Immunol. (1983) 52:153-6.

116. Edwards KM, Alford R, Gewurz H, Mold C. Recurrent bacterial infections associated with C3 nephritic factor and hypocomplementemia. N Engl J Med. (1983) 308:1138-41. doi: 10.1056/NEJM198305123081907 
117. Teisner B, Brandslund I, Folkersen J, Rasmussen JM, Poulsen LO, Svehag SE. Factor I deficiency and C3 nephritic factor: immunochemical findings and association with Neisseria meningitidis infection in two patients. Scand J Immunol. (1984) 20:291-7. doi: 10.1111/j.1365-3083.1984.tb01005.x

118. Teisner B, Elling $\mathrm{P}$, Svehag SE, Poulsen L, Lamm LU, Sjöholm A. C3 nephritic factor in a patient with recurrent neisseria meningitidis infections. Acta Pathol Microbiol Immunol Scand C. (1984) 92:341-9. doi: 10.1111/j.1699-0463.1984.tb00098.x

119. Strate $M$, Olsen $H$, Teisner B. Bactericidal capacity against neisseria meningitidis of normal human serum and sera with functional deficiencies of the third and eight complement factor. Eur J Clin Invest. (1987) 17:226-30. doi: 10.1111/j.1365-2362.1987.tb01240.x

120. Fernandez-Sola J, Monforte R, Ponz E, Lozano F, Plana M, Montoliu J, Torras A, et al. Persistent low C3 levels associated with meningococcal meningitis and membranoproliferative glomerulonephritis. Am J Nephrol. (1990) 10:426-30. doi: 10.1159/000168162

121. Hulton SA, Risdon RA, Dillon MJ. Mesangiocapillary glomerulonephritis associated with meningococcal meningitis, C3 nephritic factor and persistently low complement C3 and C5. Pediatr Nephrol. (1992) 6:239-43. doi: 10.1007/BF00878356

122. Davis CA, McAdams AJ, Wyatt RJ, Forristal J, McEnery PT, West CD. Idiopathic rapidly progressive glomerulonephritis with C3 nephritic factor and hypocomplementemia. J Pediatr. (1979) 94:559-63. doi: 10.1016/S0022-3476(79)80010-4

123. Endre ZH, Pussell BA, Charlesworth JA, Coovadia HM, Seedat YK. C3 metabolism in acute glomerulonephritis: implications for sites of complement activation. Kidney Int. (1984) 25:937-41. doi: 10.1038/ki.1984.113

124. Frémeaux-Bacchi V, Weiss L, Demouchy C, May A, Palomera S, Kazatchkine MD. Hypocomplementaemia of poststreptococcal acute glomerulonephritis is associated with $\mathrm{C} 3$ nephritic factor $(\mathrm{C} 3 \mathrm{NeF}) \operatorname{IgG}$ autoantibody activity. Nephrol Dial Transplant. (1994) 9:1747-50.

125. West CD, Witte DP, McAdams AJ. Composition of nephritic factorgenerated glomerular deposits in membranoproliferative glomerulonephritis type 2. Am J Kidney Dis. (2001) 37:1120-30. doi: 10.1053/ajkd. 2001.24511

126. Ekdahl KN, Persson B, Mohlin C, Sandholm K, Skattum L, Nilsson B. Interpretation of serological complement biomarkers in disease. Front Immunol. (2018) 9:2237. doi: 10.3389/fimmu.2018.02237

127. Goodship THJ, Pappworth IY, Toth T, Denton M, Houlberg K, McCormick F, et al. Factor $\mathrm{H}$ autoantibodies in membranoproliferative glomerulonephritis. Mol Immunol. (2012) 52:200-6. doi: 10.1016/j.molimm.2012.05.009

128. Durey M-AD, Sinha A, Togarsimalemath SK, Bagga A. Anti-complementfactor H-associated glomerulopathies. Nat Rev Nephrol. (2016) 12:563-78. doi: 10.1038/nrneph.2016.99

129. Strobel S, Zimmering M, Papp K, Prechl J, Józsi M. Anti-factor B autoantibody in dense deposit disease. Mol Immunol. (2010) 47:1476-83. doi: 10.1016/j.molimm.2010.02.002

130. Blanc C, Togarsimalemath SK, Chauvet S, Le Quintrec M, Moulin B, Buchler $\mathrm{M}$, et al. Anti-factor $\mathrm{H}$ autoantibodies in $\mathrm{C} 3$ glomerulopathies and in atypical hemolytic uremic syndrome: one target, two diseases. J Immunol. (2015) 194:5129-38. doi: 10.4049/jimmunol.1402770

131. Levy M, Halbwachs-Mecarelli L, Gubler MC, Kohout G, Bensenouci A, Niaudet $P$, et al. $H$ deficiency in two brothers with atypical dense intramembranous deposit disease. Kidney Int. (1986) 30:949-56. doi: $10.1038 / \mathrm{ki} .1986 .278$

132. Dragon-Durey M-A, Frémeaux-Bacchi V, Loirat C, Blouin J, Niaudet P, Deschenes $\mathrm{G}$, et al. Heterozygous and homozygous factor $\mathrm{h}$ deficiencies associated with hemolytic uremic syndrome or membranoproliferative glomerulonephritis: report and genetic analysis of 16 cases. J Am Soc Nephrol. (2004) 15:787-95. doi: 10.1097/01.ASN.0000115702.28859.A7

133. Licht C, Heinen S, Józsi M, Löschmann I, Saunders RE, Perkins SJ, et al. Deletion of Lys224 in regulatory domain 4 of factor $\mathrm{H}$ reveals a novel pathomechanism for dense deposit disease (MPGN II). Kidney Int. (2006) 70:42-50. doi: 10.1038/sj.ki.5000269

134. Chauvet S, Roumenina LT, Bruneau S, Marinozzi MC, Rybkine T, Schramm EC, et al. A familial C3GN secondary to defective C3 regulation by complement receptor 1 and complement factor H. J Am Soc Nephrol. (2016) 27:1665-77. doi: 10.1681/ASN.2015040348

135. Martínez-Barricarte R, Heurich M, Valdes-Cañedo F, Vazquez-Martul E, Torreira E, Montes $\mathrm{T}$, et al. Human C3 mutation reveals a mechanism of dense deposit disease pathogenesis and provides insights into complement activation and regulation. J Clin Invest. (2010) 120:3702-12. doi: 10.1172/JCI43343

136. Imamura $\mathrm{H}$, Konomoto $\mathrm{T}$, Tanaka E, Hisano S, Yoshida $\mathrm{Y}$, Fujimura $\mathrm{Y}$, et al. Familial C3 glomerulonephritis associated with mutations in the gene for complement factor B. Nephrol Dial Transplant. (2015) 30:862-4. doi: $10.1093 / \mathrm{ndt} / \mathrm{gfv} 054$

137. Gale DP, de Jorge EG, Cook HT, Martinez-Barricarte R, Hadjisavvas A, McLean AG, et al. Identification of a mutation in complement factor H-related protein 5 in patients of Cypriot origin with glomerulonephritis. Lancet. (2010) 376:794-801. doi: 10.1016/S0140-6736 (10)60670-8

138. Medjeral-Thomas N, Malik TH, Patel MP, Toth T, Cook HT, Tomson C, et al. A novel CFHR5 fusion protein causes C3 glomerulopathy in a family without Cypriot ancestry. Kidney Int. (2014) 85:933-7. doi: 10.1038/ki.2013.348

139. Malik TH, Lavin PJ, Goicoechea de Jorge E, Vernon KA, Rose KL, Patel MP, et al. A hybrid CFHR3-1 gene causes familial C3 glomerulopathy. J Am Soc Nephrol. (2012) 23:1155-60. doi: 10.1681/ASN. 2012020166

140. Goicoechea de Jorge E, Caesar JJE, Malik TH, Patel M, Colledge M, Johnson $\mathrm{S}$, et al. Dimerization of complement factor $\mathrm{H}$-related proteins modulates complement activation in vivo. Proc Natl Acad Sci USA. (2013) 110:4685-90. doi: 10.1073/pnas.1219260110

141. Tortajada A, Yébenes H, Abarrategui-Garrido C, Anter J, García-Fernández JM, Martínez-Barricarte R, et al. C3 glomerulopathy-associated CFHR1 mutation alters FHR oligomerization and complement regulation. J Clin Invest. (2013) 123:2434-46. doi: 10.1172/JCI68280

142. Chen Q, Wiesener M, Eberhardt HU, Hartmann A, Uzonyi B, Kirschfink $\mathrm{M}$, et al. Complement factor H-related hybrid protein deregulates complement in dense deposit disease. J Clin Invest. (2014) 124:145-55. doi: 10.1172/JCI71866

143. Xiao X, Ghossein C, Tortajada A, Zhang Y, Meyer N, Jones M, et al. Familial C3 glomerulonephritis caused by a novel CFHR5-CFHR2 fusion gene. Mol Immunol. (2016) 77:89-96. doi: 10.1016/j.molimm.2016.07.007

144. Häffner K, Michelfelder S, Pohl M. Successful therapy of C3Nef-positive C3 glomerulopathy with plasma therapy and immunosuppression. Pediatr Nephrol. (2015) 30:1951-9. doi: 10.1007/s00467-015-3111-9

145. Kurtz KA, Schlueter AJ. Management of membranoproliferative glomerulonephritis type II with plasmapheresis. J Clin Apher. (2002) 17:135-7. doi: 10.1002/jca.10026

146. Faedda R, Satta A, Tanda F, Pirisi M, Bartoli E. Immunosuppressive treatment of membranoproliferative glomerulonephritis. Nephron. (1994) 67:59-65. doi: 10.1159/000187889

147. Bahat E, Akkaya BK, Akman S, Karpuzoglu G, Guven AG. Comparison of pulse and oral steroid in childhood membranoproliferative glomerulonephritis. J Nephrol. (2007) 20:234-245.

148. Rabasco C, Cavero T, Román E, Rojas-Rivera J, Olea T, Espinosa M, et al. Effectiveness of mycophenolate mofetil in C3 glomerulonephritis. Kidney Int. (2015) 88:1153-60. doi: 10.1038/ki.2015.227

149. Payette A, Patey N, Dragon-Durey M-A, Frémeaux-Bacchi V, Le Deist F, Lapeyraque A-L. A case of C3 glomerulonephritis successfully treated with eculizumab. Pediat Nephrol. (2015) 30:1033-7. doi: 10.1007/s00467-015-3061-2

150. Giaime P, Daniel L, Burtey S. Remission of C3 glomerulopathy with rituximab as only immunosuppressive therapy. Clin Nephrol. (2015) 83:5760. doi: 10.5414/CN107945

151. Rousset-Rouvière C, Cailliez M, Garaix F, Bruno D, Laurent D, Tsimaratos M. Rituximab fails where eculizumab restores renal function in C3nefrelated DDD. Pediatr Nephrol. (2014) 29:1107-11. doi: 10.1007/s00467013-2711-5

152. Rudnicki M. Rituximab for treatment of membranoproliferative glomerulonephritis and C3 glomerulopathies. Biomed Res Int. (2017) 2017:2180508. doi: 10.1155/2017/2180508 
153. Vivarelli M, Emma F. Treatment of C3 glomerulopathy with complement blockers. Semin Thromb Hemost. (2014) 40:472-7. doi: 10.1055/s-0034-1375299

154. Le Quintrec M, Lapeyraque A-L, Lionet A, Sellier-Leclerc A-L, Delmas Y, Baudouin V, et al. Patterns of clinical response to eculizumab in patients with C3 glomerulopathy. Am J Kidney Dis. (2018) 72:84-92. doi: 10.1053/j.ajkd.2017.11.019

155. Zhang Y, Nester CM, Holanda DG, Marsh HC, Hammond RA, Thomas LJ, et al. Soluble CR1 therapy improves complement regulation in C3 glomerulopathy. J Am Soc Nephrol. (2013) 24:1820-9. doi: 10.1681/ASN.2013010045
Conflict of Interest Statement: The authors declare that the research was conducted in the absence of any commercial or financial relationships that could be construed as a potential conflict of interest.

Copyright (c) 2019 Corvillo, Okrój, Nozal, Melgosa, Sánchez-Corral and LópezTrascasa. This is an open-access article distributed under the terms of the Creative Commons Attribution License (CC BY). The use, distribution or reproduction in other forums is permitted, provided the original author(s) and the copyright owner(s) are credited and that the original publication in this journal is cited, in accordance with accepted academic practice. No use, distribution or reproduction is permitted which does not comply with these terms. 